\title{
Trends in rainfall and extreme temperatures in northwestern Mexico
}

\author{
Oscar G. Gutiérrez-Ruacho ${ }^{1}$, Luis Brito-Castillo ${ }^{2,3}{ }^{*}$, Sara C. Díaz-Castro1, \\ Christopher J. Watts ${ }^{4}$ \\ ${ }^{1}$ Centro de Investigaciones Biológicas del Noroeste (CIBNOR), La Paz, BCS 23096, México \\ ${ }^{2}$ CIBNOR, Guaymas, Sonora 85454, México \\ ${ }^{3}$ Centro Universitario de Ciencias Exactas e Ingeniería, Departamento de Física, Universidad de Guadalajara, Guadalajara, \\ Jalisco 44430, México \\ ${ }^{4}$ Universidad de Sonora, Hermosillo, Sonora 83000, México
}

\begin{abstract}
The impact of global warming across northwestern Mexico is difficult to discern because long-term climatic data series are lacking, and this semi-arid region is subject to strong seasonal variability. Using data between 1922 and 2004 from 55 weather stations located in the State of Sonora, the Baja California Peninsula, and some stations in the United States near the Mexican border, we analyzed trends observed for weather variables. The magnitude and statistical significance of trends were determined, using the least squares regression procedure. Microregional series were delimited after applying varimax rotated empirical orthogonal functional analysis to the weather series. The limits between the 9 microregions were defined by considering a rotated factor loading $\geq 0.6$. Series with significant trends were correlated with 5 different climatic indices: Pacific Decadal Oscillation, Atlantic Multi-decadal Oscillation, Southern Oscillation Index, North Atlantic Oscillation Index, and values of $700 \mathrm{hPa}$ geopotential height anomalies. Results show that northwestern Mexico has high meteorological heterogeneity, as observed in spatial and seasonal variability of precipitation and temperature. Different trends were found across the region. Correlation analyses indicate that trends in several variables are associated with inter-decadal changes in the Pacific and the Atlantic, as well as with variations of the $700 \mathrm{hPa}$ atmospheric flow patterns, changes in sea surface temperatures, penetration of extratropical fronts, and, for the State of Baja California Sur, higher incidence of tropical cyclones.
\end{abstract}

KEY WORDS: Tendencies $\cdot$ Extreme values $\cdot$ Northwestern Mexico $\cdot$ Drought $\cdot$ Climate variability

\section{INTRODUCTION}

The report of the Intergovernmental Panel on Climate Change concluded that average global temperature increased by $0.74^{\circ} \mathrm{C}$ over the past century and is now increasing more rapidly (IPCC 2007). The effects of warming on production of food and management of water resources have been discussed in numerous papers (e.g. Brown \& Funk 2008, Milly et al. 2008). The consequences of changes can be interferred from diverse meteorological variables, but are particularly obvious in extreme weather events, leading to severe economic losses and human catastrophes (Karl \& Easterling 1999, Easterling et al. 2000).
The situation is more complicated because the effects of global warming at regional levels are poorly known (Overpeck \& Cole 2006, IPCC 2007). For example, specific regional changes in extreme weather events, heat waves, cold waves, and number of days that exceed some specified temperature are unknown (Easterling et al. 2000). Hence it is essential to document and understand where, how, and the frequency at which regional climate change is taking place (Thielen \& Centeno 2007). For example, Yan et al. (2002) reported an increase in maximum temperatures for Western Europe. In England, increased temperature is manifested as a reduction of cold days (Jones et al. 1999). In northern and central Europe, the increase in 
minimum temperatures has a greater magnitude than the increase of maximum temperatures (Heino et al. 1999). In Mexico, Englehart \& Douglas (2005) showed an increase in the diurnal range of minimum and maximum temperatures, which they associated to changes in land management. On a regional scale in Mexico, Weiss \& Overpeck (2005) reported a reduction in the frost-free season in the Sonoran Desert, and associated this with an increase in minimum temperatures. BritoCastillo et al. (2009) showed a temperature dipole for central Mexico, in part associated with changes observed in the $700 \mathrm{hPa}$ atmospheric flow patterns.

Given inherent high variability in local precipitation patterns, climate trends from weather station data can appear inconsistent. This is particularly the case in the arid and semi-arid lands of southwestern Arizona and northwestern Mexico (Comrie \& Broyles 2002). Climate in this area is strongly influenced by El Niño Southern Oscillation (ENSO) events, which is considered one of the more important global modulators of interannual climatic variability. The El Niño phase of ENSO favors wet conditions during summers of cold-phase Pacific Decadal Oscillation (PDO) and during winters of warmphase PDO in the northwestern-most part of Mexico, whereas La Niña exhibits precipitation conditions opposite to the ones produced by El Niño (Pavía et al. 2006).

In the southwestern United States and parts of northwestern Mexico, recent climate change models predict a tendency toward a drier and warmer climate (Seager

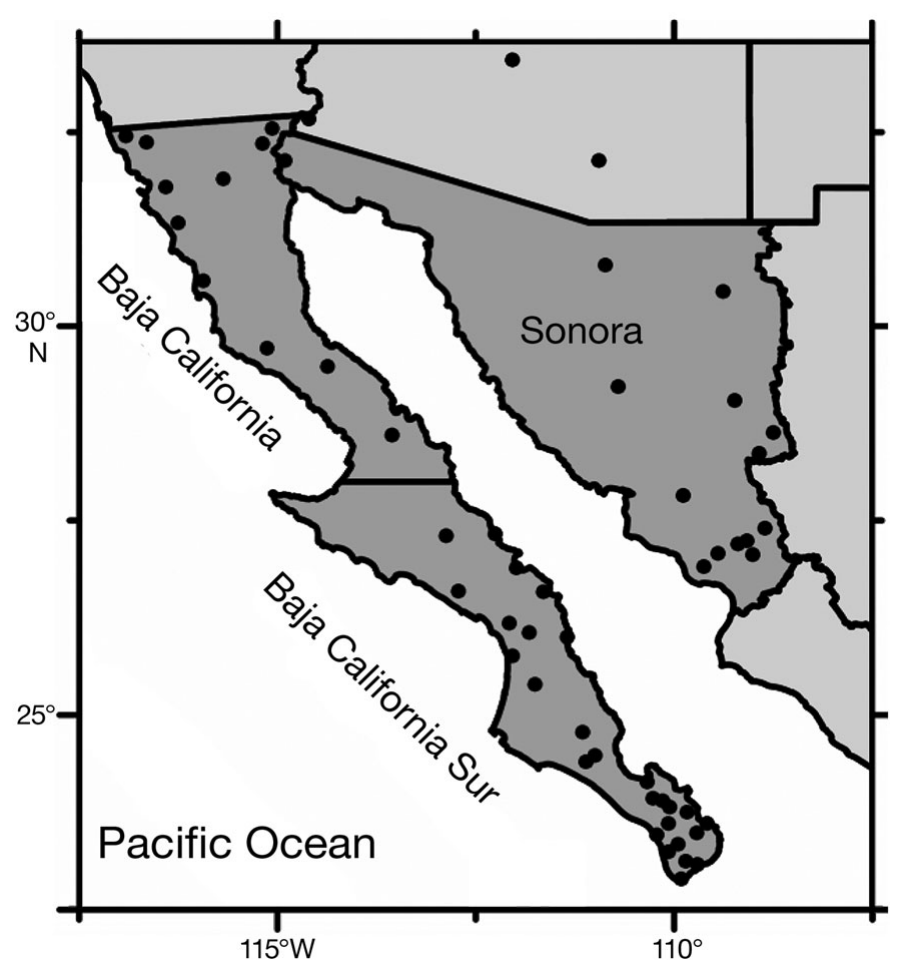

Fig. 1. Study area. Location of weather stations selected for analyzing local climatic trends are indicated by filled circles et al. 2007). These predictions may not be valid for the southern Baja California Peninsula; however, Díaz et al. (2008) noted that, in recent years, the number of tropical cyclones has stayed fairly constant and constitutes an important source of rainfall in the region during the summer. At the global scale, the number of cyclones may be increasing (Hoyos et al. 2006).

With high seasonal and spatial variability of temperature and precipitation in northwestern Mexico and especially in the Sonoran Desert (which includes the driest locations in North America; Turner et al. 2003), several studies have characterized regional climatic variability (Shreve 1914, 1944, Hastings \& Turner 1965, Ezcurra \& Rodríguez 1986, Schmidt 1989, Douglas et al. 1993, Pavía \& Graef 2002, Weiss \& Overpeck 2005). While several studies have dealt with climate in northwestern Mexico, regional climatic changes need to be based on long-term tendencies in the weather data to identify the nature of the changes in this region. The present study analyzed the magnitude of extreme changes in temperature and precipitation in northwestern Mexico using meteorological data from the past 8 decades.

\section{MATERIALS AND METHODS}

\subsection{Study area}

Northwestern Mexico encompasses the States of Baja California, Baja California Sur, and Sonora. The Pacific Ocean and the Gulf of California strongly influence the climate of this region (Fig. 1). Generally, conditions are dry and warm to hot, as is typical of the Sonoran Desert (Turner et al. 2003). The region is under the influence of the prevailing westerlies most of the year, while the subtropical anticyclone and the Mexican monsoon circulation are strong influences in the summer and early fall (Vera et al. 2006). The climate of the study area is marked by a transition between the region influenced by the Mexican monsoon and the Mediterranean climate of California (Comrie \& Glenn 19988). Precipitation increases towards the southeast, with summer receiving the most rainfall, while in the northwest, winter rains are more common (Vera et al. 2006).

\subsection{Data}

We used daily data of maximum temperature, minimum temperature, and precipitation between 1922 and 2004 from weather stations in the States of Sonora, Baja California, Baja California Sur, and the southern part of Arizona and California. For Mexico, the data were ob- 
tained from the Extractor Rápido de Información Climatológica (ERIC III) database created by the Mexican Institute of Water Technology. For stations in the United States, data were obtained from the National Climatic Data Center (http://iridl.ldeo.columbia.edu/SOURCES/ .NOAA/.NCDC/.DAILY/.FSOD/searches.html). For the study region, 583 weather stations were found in Mexico and 30 in the United States. Of these meteorological stations, 55 were selected that fulfilled our criteria, which was that stations must: (1) have a large number of daily observations over many years, and (2) be located outside large cities to avoid heat island effects. Selection was also biased toward stations that provided a greater homogeneity of spatial distribution throughout the area. We selected 14 stations in Sonora, 11 in Baja California, 27 in Baja California Sur, and 3 in Arizona (Fig. 1).

We selected the following rainfall and temperature variables for analysis:

(1) Total annual rainfall (TAR, mm).

(2) Total days with rainfall $>0.0 \mathrm{~mm}\left(\mathrm{TDR}_{>0}\right)$; in some cases, original printed data has the legend 'INAP' which means 'imperceptible'. In these instances we listed the value as $0.01 \mathrm{~mm}$.

(3) Total days with rainfall $\geq 10 \%$ of the historic maximum $\left(\mathrm{TDR}_{\geq 10}\right)$, determined by finding the following values in each series: $\mathrm{R}_{\max }$ (heaviest rainfall of the series in $\mathrm{mm}$ ); $\mathrm{n}$ (total days with records); $\mathrm{n}_{\mathrm{r}}$ (total days with rainfall $>0$ ) $; \mathrm{n}_{\mathrm{r} 10 \%}$ (upper $10 \%$ fraction of $\mathrm{n}_{\mathrm{r}}$ ); and $\mathrm{n}_{\mathrm{r}}{ }^{\prime}$ (threshold value separating $\mathrm{n}_{\mathrm{r} 10 \%}$ from the rest of the values $[\mathrm{mm}])$.

Necessarily, $\mathrm{n}_{\mathrm{r}}{ }^{\prime}<\mathrm{R}_{\max }$ (an appropriate value for $\mathrm{n}_{\mathrm{r}}{ }^{\prime}$ is found such that the number of days with rainfall above $\mathrm{n}_{\mathrm{r}}{ }^{\prime}$ equals or nearly equals $\mathrm{n}_{\mathrm{r} 10 \%}$ ). Once $\mathrm{n}_{\mathrm{r}}{ }^{\prime}$ was found, this threshold value was used to quantify the days with rainfall above $\mathrm{n}_{\mathrm{r}}{ }^{\prime}$ per year. After this procedure was completed, a new series was formed showing the number of days with rainfall above the threshold value each year. Regression analysis of the new series measured the tendency.

(4) Minimum annual average temperature $\left(\mathrm{T}_{\min },{ }^{\circ} \mathrm{C}\right)$, calculated using the mean of daily values of minimum temperature during the year.

(5) Total days with temperatures $\leq 10 \%$ of the historic minimum $\left(\mathrm{TDT}_{\min \leq 10}\right)$. The procedure is the same as (3), except that the complete series of minimum temperatures was used (considering positive and negative data).

(6) Maximum annual average temperature $\left(T_{\max }\right.$ ${ }^{\circ} \mathrm{C}$ ), calculated using the mean of the daily values of maximum temperatures during the year.

(7) Total days with temperatures $\geq 10 \%$ of the historical maximum $\left(\mathrm{TDT}_{\max \geq 10}\right)$. The procedure is the same as (3), except that the complete series of maximum temperatures was used.

\subsection{Regionalization}

For each variable, empirical orthogonal functional analysis (EOFA) was independently applied with varimax rotation of the resultant axes to retain the most important modes of variation. This analysis is similar to principal components analysis (PCA), but takes into account spatial and seasonal patterns in the data, which is essential for long-term series of data. Factors were extracted from a correlation matrix, with case-wise deletion of missing data. Here, only those values that are common to all the series were included in the computations. Initially, provisional, unrotated factor loadings $\left(a_{i j}{ }^{\prime}\right)$ were determined. For this purpose, PCA, with an a priori minimum eigenvalue of 1.0, was used. In the second phase of calculations (factor rotation), only those factors that together explained between 45 and $63 \%$ of the total variance in the original series, taking into account the analysis of effective degeneracy, were considered, as discussed by North et al. (1982).

The rotated factor loadings $\left(a_{i j}\right)$ of each factor were then plotted on a map to analyze spatial distribution. The boundaries between microregions were defined by $a_{i j} \geq 0.6$. The microregional series related to $a_{i j}$ leading modes of each variable (number of leading modes were different for each variable, either 3 or 4) were obtained by averaging the standardized values of the series with $a_{i j}>0.6$.

From linear approximation, the tendency of each microregional series was obtained by the method of minimal least squares errors, with years as independent values and serial data within each year as dependent values.

To match tendencies in the EOFA with climatic indices, we used Pearson's correlation analyses to relate data series with significant trends $(p<0.05)$ with the following indices: (1) Pacific Decadal Oscillation (PDO; Mantua et al. 1997); (2) Atlantic Multi-decadal Oscillation (AMO; Barnston \& Livezey 1987, Enfield et al. 2001); (3) Southern Oscillation Index (SOI; BOM 2010); (4) North Atlantic Oscillation (NAO; NOAA 2002); and (5) anomalies of the $700 \mathrm{hPa}$ geopotential heights (GH700) displayed in a $2.5^{\circ} \times 2.5^{\circ}$ grid (NOAA ESRL 2006).

\section{RESULTS}

From the EOFA, 3 or 4 factors were retained for each of the variables (North et al. 1982). The geographic distribution of the factor loadings for each leading mode and variable is shown in Fig. 2. In this figure, we differentiated 9 microregions with loading contours >0.6. These microregions are: northwestern Baja California (NWBC); southern Baja California (SBC); northern Baja California Sur (NBCS); central Baja California Sur 
$\mathrm{F} 1$

F2

F3

F4
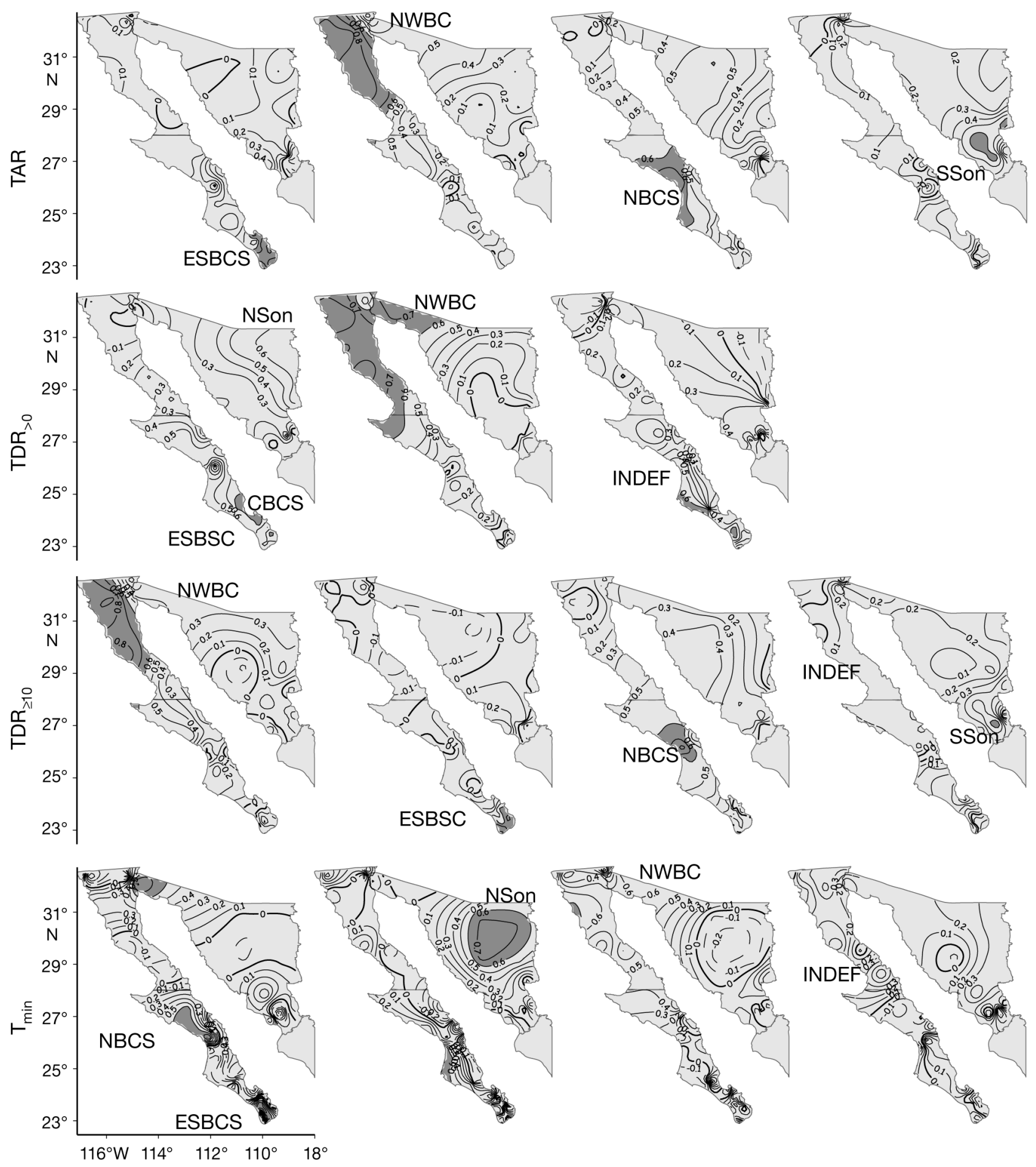

Fig. 2. (Above and facing page) Geographic distribution of the rotated factor loadings $\left(a_{i j}\right)$ for each leading mode and variable. Dark gray: distribution of significant $\left(a_{i j}\right)$ for each climatic factor (F1 to F4) identified by the analysis of empirical orthogonal functions with varimax axis rotation. TAR: total annual rainfall $(\mathrm{mm})_{;} \mathrm{TDR}_{>0}$ : total days in the year with rainfall $>0 \mathrm{~mm}$ TDR $\mathrm{T}_{\geq 10}$ : total days in the year with rainfall of the historic maximum; $\mathrm{T}_{\min }$ : annual mean minimum temperature $\left({ }^{\circ} \mathrm{C}\right) ; \mathrm{TDT}_{\min \leq 10}$ : total days in the year with temperatures $\leq 10 \%$ of the historic minimum; $\mathrm{T}_{\max }$ : annual mean maximum temperature $\left({ }^{\circ} \mathrm{C}\right)$; $\mathrm{TDT}_{\max \geq 10}$ : total days in the year in which temperature was $\geq 10 \%$ of the historical maximum; NWBC: northwestern Baja California; SBC: southern Baja California; NBCS: northern Baja California Sur; CBCS: central Baja California Sur; ESBCS: extreme southern Baja California Sur; NSon: northern Sonora; CSon: central Sonora; ESon: eastern Sonora; SSon: southern Sonora; INDEF: indefinite 


\section{F1}

F2

F3

F4
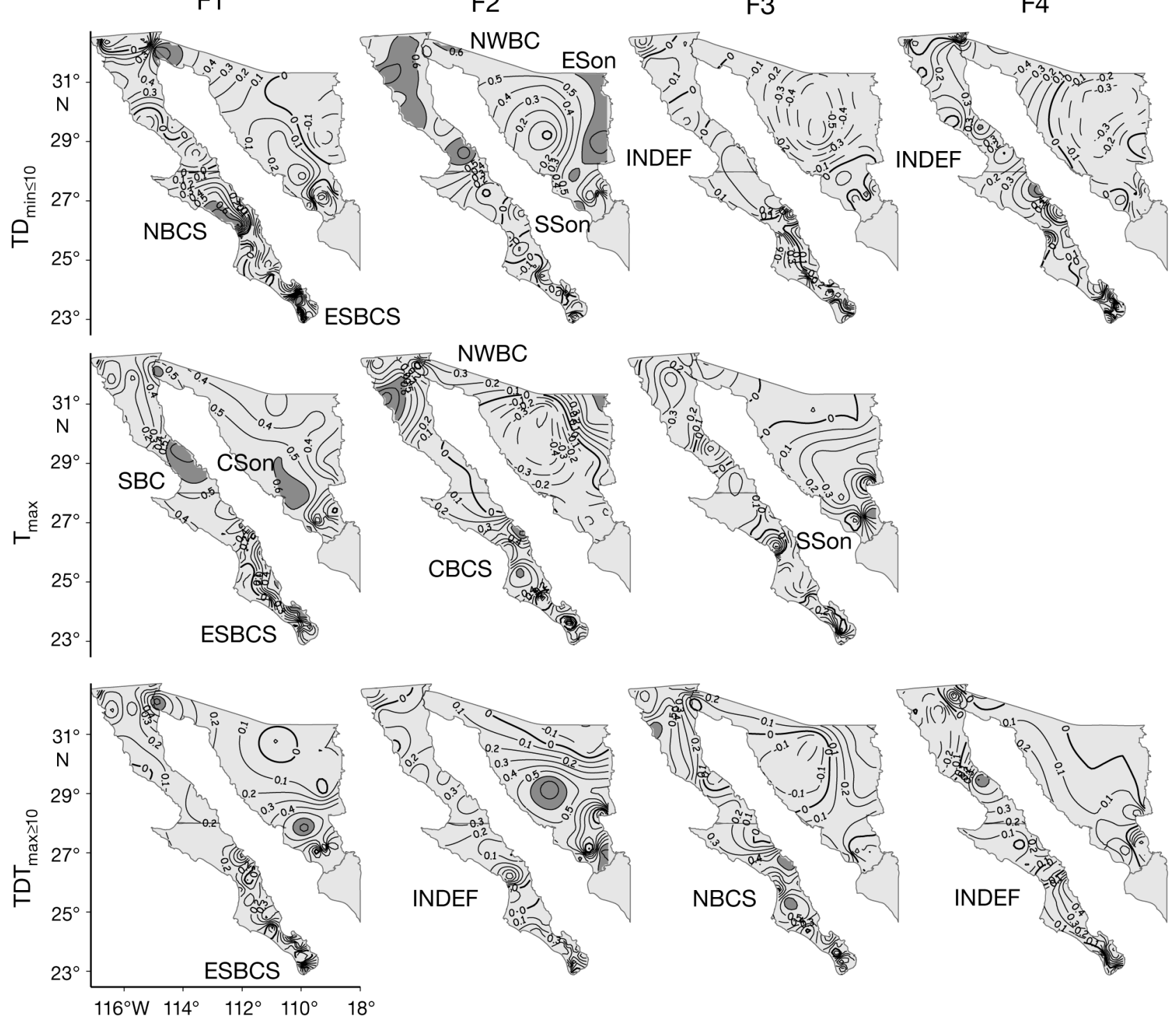

Fig. 2. (continued)

(CBCS); extreme southern Baja California Sur (ESBCS); northern Sonora (NSon); central Sonora (CSon); eastern Sonora (ESon); and southern Sonora (SSon). Although there were 28 microregional series corresponding to the leading modes, only 18 showed statistically significant trends (Table 1).

For total annual rainfall (TAR), 4 leading factors explained $58 \%$ of the original variance (Fig. 2). Analyses of trends indicate that annual rain is increasing in NWBC and NBCS and decreasing in SSon (Table 1).

For days with rainfall $>0 \mathrm{~mm}\left(\mathrm{TDR}_{>0}\right)$, 3 leading factors explained $53.7 \%$ of the original variance (Table 2 , Fig. 2) and 4 distinct microregions were delimited. Analysis of trends indicates that the number of days with measurable rain is increasing in CBCS and NSon (Table 1).
For the total days in the year during which rainfall was $\geq 10 \%$ above the historic maximum $\left(\mathrm{TDR}_{\geq 10}\right), 4$ leading factors explained $46.3 \%$ of the original variance (Table 2, Fig. 2). The microregional series show an increasing trend for this variable in NWBC and NBCS (Table 1).

For the minimum annual average temperature $\left(\mathrm{T}_{\min }\right)$, 4 leading factors explained $61.6 \%$ of the variance (Table 2, Fig. 2). The minimum annual average increased over time in NBCS and ESBCS and decreased in NSon (Table 1).

For days with temperatures $\geq 10 \%$ below the historic minimum ( $\mathrm{TDT}_{\min \geq 10}$ ), there were 4 leading factors that explained $63.8 \%$ of the variance (Table 2, Fig. 2). The microregional series show that cold days are becoming less frequent in ESBCS, NBCS, and SSon (Table 1). 
Table 1. Climatic trends in the microregional series. F: factor; P: significantly positive; N: significantly negative; NS: non-significant $(<95 \%)$ across the region. Regions are those that recurred most frequently during the analysis of empirical orthogonal functions using varimax axis rotation. $\mathrm{TDR}_{>0}$ : total days in the year with rainfall $\geq 0.1 \mathrm{~mm}$; other abbreviations as in Fig. 2

\begin{tabular}{|c|c|c|c|c|c|c|c|}
\hline Region & TAR & $\mathrm{TDR}_{>0}$ & $\mathrm{TDR}_{\geq 10}$ & $\mathrm{~T}_{\min }$ & $\mathrm{TDT}_{\min \leq 10}$ & $\mathrm{~T}_{\max }$ & $\mathrm{TDT}_{\max \geq 10}$ \\
\hline NWBC & F2-P & F2-NS & F1-P & F3-NS & $\mathrm{F} 2-\mathrm{NS}$ & F2-P & \\
\hline SBC & & & & & & F1-NS & \\
\hline $\begin{array}{l}\text { NBCS } \\
\text { CBCS }\end{array}$ & $\mathrm{F} 3-\mathrm{P}$ & F1-P & F3-P & F1-P & F1-N & & F3-P \\
\hline $\begin{array}{l}\text { CBCS } \\
\text { ESBCS }\end{array}$ & F1-NS & F1-NS & F2-NS & F1-P & F1_N & F2-P & F1-P \\
\hline $\begin{array}{l}\text { NSBCS } \\
\text { NSon }\end{array}$ & & F1-P & $12-1 \mathrm{~V}$ & F2-N & FI-N & F1-NS & $\mathrm{F} 1-\mathrm{P}$ \\
\hline CSon & & & & & & F1-N & \\
\hline ESon & & & & & F2-NS & & \\
\hline SSon & $\mathrm{F} 4-\mathrm{N}$ & & F4-NS & & $\mathrm{F} 2-\mathrm{N}$ & & \\
\hline
\end{tabular}

Pearson's correlation analyses between microregional series with statistically significant trends and different climatic indexes (PDO, AMO, SOI, NAO) show the following significant correlations: (1) $\mathrm{TDR}_{>0}$ in NSon with the PDO and SOI indices; (2) $\mathrm{T}_{\min }$ and $\mathrm{T}_{\max }$ in central Sonora with the PDO, AMO and SOI indices; (3) $\mathrm{TAR}$ and $\mathrm{TDR}_{\geq 10}$ in NWBC with the SOI; (4) $\mathrm{T}_{\max }$ in CSon, NWBC and CBCS with the PDO and SOI indices; (5) TAR in NBCS with the NAO index; (6) $\mathrm{TDT}_{\max \geq 10}$ in NBCS with the NAO and SOI indices; and (7) $\mathrm{T}_{\min }$ and $\mathrm{TDT}_{\min \leq 10}$ in NBCS with the PDO, SOI, and AMO indices (Table 3).

For maximum annual average temperature $\left(\mathrm{T}_{\max }\right), 3$ leading factors explained $45.4 \%$ of the variance (Table 2 , Fig. 2). The microregional series show that maximum annual average temperatures increased in NWBC and CBCS and decreased in CSon (Table 1).

For days in a year with a maximum temperature $\geq 10 \%$ above the historical maximum $\left(\mathrm{TDT}_{\max } \geq 10\right), 4$ leading factors explained $48.4 \%$ of the total variance. NBCS and ESBCS have increased frequency of hotter days (Table 1).

Table 2. Variance explained by each ordination factor for the local climatic variables that had statistically significant trends. Abbreviations as in Fig. 2

\begin{tabular}{|c|c|c|c|}
\hline Variable & Factor & Variance explained & Total \\
\hline TAR & $\begin{array}{l}1 \\
2 \\
3 \\
4\end{array}$ & $\begin{array}{r}17.79 \\
16.98 \\
14.29 \\
8.94\end{array}$ & 58.0 \\
\hline $\mathrm{TDR}_{>0}$ & $\begin{array}{l}1 \\
2 \\
3\end{array}$ & $\begin{array}{l}22.17 \\
17.84 \\
13.65\end{array}$ & 53.66 \\
\hline $\mathrm{TDR}_{\geq 10}$ & $\begin{array}{l}1 \\
2 \\
3 \\
4\end{array}$ & $\begin{array}{r}15.05 \\
11.23 \\
11.35 \\
8.65\end{array}$ & 46.28 \\
\hline $\mathrm{T}_{\min }$ & $\begin{array}{l}1 \\
2 \\
3 \\
4\end{array}$ & $\begin{array}{r}20.57 \\
15.48 \\
15.58 \\
9.91\end{array}$ & 61.55 \\
\hline $\mathrm{TDT}_{\min \leq 10}$ & $\begin{array}{l}1 \\
2 \\
3 \\
4\end{array}$ & $\begin{array}{l}19.9 \\
20.22 \\
10.6 \\
13.01\end{array}$ & 63.8 \\
\hline $\mathrm{T}_{\max }$ & $\begin{array}{l}1 \\
2 \\
3\end{array}$ & $\begin{array}{l}18.72 \\
16.33 \\
10.34\end{array}$ & 45.30 \\
\hline $\mathrm{TDT}_{\max \geq 10}$ & $\begin{array}{l}1 \\
2 \\
3 \\
4\end{array}$ & $\begin{array}{r}12.9 \\
11.94 \\
14.07 \\
9.65\end{array}$ & 48.35 \\
\hline
\end{tabular}

In $\mathrm{CBCS}$, there was a significant correlation between $\mathrm{TDR}_{>0}$ and the PDO and SOI indices. In ESBCS, there was a significant correlation between $\mathrm{T}_{\min }$ and the PDO, AMO, and SOI indices, as well as $\mathrm{TDT}_{\min \leq 10}$ with the PDO and SOI indices; also, $\mathrm{TDT}_{\max \geq 10}$ was correlated with the AMO index (Table 3).

Fewer significant correlations were found between the climatic variables and GH700 data. In NWBC, TAR and $\mathrm{TDR}_{\geq 10}$ were correlated with GH700 (Fig. 3). In ESBCS, $\mathrm{T}_{\min }$ correlated with GH700.

Table 3. Pearson's correlation coefficients between local climatic variables and regional climatic indices for various geographic regions. PDO: Pacific Decadal Oscillation; AMO: Atlantic Multi-decadal Oscillation; SOI: Southern Oscillation Index; NAO: North Atlantic Oscillation. Abbreviations as in Fig. 2. Bold: significant

\begin{tabular}{|c|c|c|c|c|c|}
\hline \multirow[t]{2}{*}{ Variable } & \multirow[t]{2}{*}{ Region } & \multicolumn{4}{|c|}{ - Regional climatic index } \\
\hline & & PDO & AMO & SOI & NAO \\
\hline \multirow[t]{3}{*}{ TAR } & NWBC & 0.17 & -0.08 & -0.34 & -0.07 \\
\hline & NBCS & 0.19 & -0.08 & -0.26 & 0.39 \\
\hline & SSon & 0.06 & -0.04 & -0.04 & 0.20 \\
\hline \multirow[t]{2}{*}{$\mathrm{TDR}_{>0}$} & CBCS & 0.34 & -0.15 & -0.32 & 0.30 \\
\hline & NSon & 0.45 & 0.02 & -0.45 & 0.10 \\
\hline \multirow[t]{2}{*}{$\mathrm{TDR}_{\geq 10}$} & NWBC & 0.14 & -0.11 & -0.31 & -0.06 \\
\hline & NBCS & 0.17 & -0.22 & -0.27 & 0.23 \\
\hline \multirow[t]{3}{*}{$\mathrm{T}_{\min }$} & NBCS & 0.47 & 0.28 & -0.27 & 0.16 \\
\hline & ESBCS & 0.25 & 0.32 & -0.29 & 0.00 \\
\hline & NSon & -0.29 & 0.42 & 0.14 & 0.11 \\
\hline \multirow[t]{3}{*}{$\mathrm{TDT}_{\min \leq 10}$} & NBCS & -0.36 & -0.33 & 0.26 & -0.21 \\
\hline & ESBCS & -0.43 & -0.26 & 0.25 & -0.11 \\
\hline & ESon & -0.33 & 0.27 & 0.22 & -0.01 \\
\hline \multirow[t]{3}{*}{$\mathrm{T}_{\max }$} & CSon & -0.44 & 0.59 & 0.31 & 0.09 \\
\hline & NWBC & 0.36 & 0.18 & -0.32 & 0.05 \\
\hline & $\mathrm{CBCS}$ & 0.37 & 0.07 & -0.32 & 0.14 \\
\hline \multirow[t]{2}{*}{$\mathrm{TDT}_{\max \geq 10}$} & ESBCS & 0.04 & 0.57 & -0.13 & 0.11 \\
\hline & NBCS & 0.09 & 0.33 & -0.20 & 0.15 \\
\hline
\end{tabular}



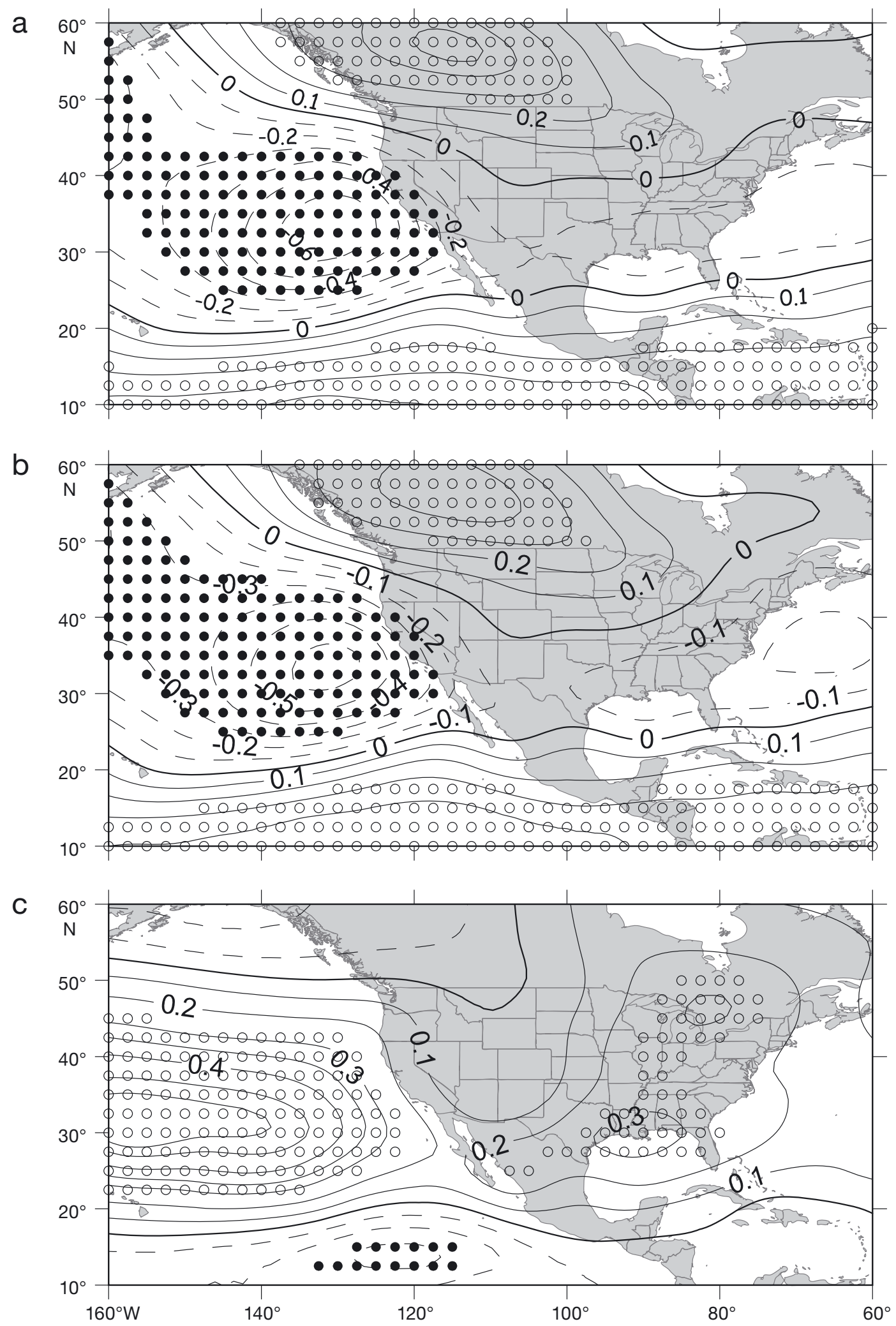

Fig. 3. Contour plot of positive (solid line) and negative (dashed line) correlations between the 700 mb geopotential height anomalies and (a) total annual rainfall in northwestern Baja California (NWBC), (b) frequency of maximum precipitation in NWBC, and (c) frequency of minimum temperatures in extreme southern Baja California Sur (ESBCS). Open, closed circles: significantly positve or negative correlations, repectively, at the 0.01 level of confidence 


\section{DISCUSSION}

The factors ( $\mathrm{F} 1$ to $\mathrm{F} 4$ ) of the variables consistently differentiated geographic climatic microregions within the larger region. Together, these factors explained $45 \%$ of the variance explained in the original series in $\mathrm{T}_{\max }$ and as much as $64 \%$ for $\mathrm{TDT}_{\min \leq 10}$ (Table 2). Despite these resemblances, the geographic distribution of the defined microregions and the patterns of climate variation between them are very heterogeneous (Fig. 2) and are not very evident from the geographic conditions at the boundaries between the microregions. With variables such as $\mathrm{TAR}$ and $\mathrm{TDR}_{\geq 10 \%}$ in each retained factor, rotated factor loadings $\left(a_{i j}\right)>0.60$ are clustered in specific geographic microregions. For other variables, the contours of $a_{i j}>0.60$ are much broader, with areas disconnected from one another, which bring uncertain differentiation of one microregion. In this case, we formed 2 independent microregions instead of one miocroregion with a single factor; that is, for $\mathrm{TDR}_{>0}, \mathrm{~F} 1$ is split between NSon and CBCS; for $\mathrm{T}_{\min }$ and $\mathrm{TDT}_{\min \leq 10}, \mathrm{~F} 1$ is split between NBCS and ESBCS in both cases; for TDT $\mathrm{Tin}_{\text {min }}, \mathrm{F} 2$ is split between NWBC and SSon; for $\mathrm{T}_{\max }, \mathrm{F} 2$ is split between NWBC and $\mathrm{CBCS}_{\text {; }}$ and for $\mathrm{TDT}_{\max \geq 10}, \mathrm{~F} 1$ is split between ESBCS and SSon, whereas F2 is split between CSon and SSon. Although the series clustered by the leading factor reflect a single mode of variation, it appears more logical to differentiate 2 microregions, as those mentioned above, when they are separated geographically. Also, there are situations where the geographic region is indefinite (Fig. 2). Heterogeneity in patterns indicates the complexity of factors in regional climatic variability.

Despite great variability, it is possible to focus analyses on the microregions that appear more frequently (Fig. 2). For example, the NWBC, ESBCS, and SSon microregions appear more frequently on the maps (Fig. 2), whereas the CBCS, NSon, and CSon microregions appear less frequently.

The NWBC microregion, of Mediterranean climate, has received much attention (Hastings \& Turner 1965, Comrie \& Glenn 1998, Cavazos \& Rivas 2004, Cavazos et al. 2008). Pavía \& Graef (2002) showed positive trends over the historic record in $\mathrm{TAR}, \mathrm{TDR}_{\geq 10}$, and $\mathrm{T}_{\max }$. Increasing rainfall is associated with more frequent intrusion of extratropical fronts from the northwest and negative correlations between TAR and GH700 (Fig. 3a). The pattern of atmospheric flow is very similar to those described by Brito-Castillo et al. (2003) as typical for wet winters, with negative anomalies of GH700 that spread from the North Pacific and cross northern Mexico toward the southeastern United States. It appears that wet winter patterns intensify during El Niño events and positive phases of the PDO
(Pavía \& Graef 2002, Cavazos \& Rivas 2004, Cavazos et al. 2008). We found that the correlation between TAR and the SOI in NWBC is statistically significant (Table 3).

In contrast, ESBCS showed positive trends in $\mathrm{T}_{\text {min }}$ and $\mathrm{TDT}_{\max \geq 10}$, but a negative trend in $\mathrm{TDT}_{\min \leq 10}$. Although this microregion is affected by tropical cyclones (Cavazos 2008, Díaz et al. 2008), the trends in TAR and $\mathrm{TDR}_{>0}$ are not statistically significant. The correlations between TAR and GH700 (Fig. 3b) show a pattern opposite to that in NWBC. This suggests that the influence of atmospheric phenomena from the middle latitudes on the generation of rain is much smaller than the influence of tropical atmospheric phenomena. Thus the atmospheric phenomena of middle latitudes are linked with positive tendencies of rainfall in northwestern Baja California, in contrast to summer atmospheric phenomena in southern Baja California, where this rainfall pattern does not occur.

In Sonora, the trend in rainfall is positive in the north $\left(\mathrm{TDR}_{>0}\right)$, and negative in the south (TAR), a phenomenon that cannot be associated with tropical cyclone occurrences because these storms usually affect extreme, but not mean, values (Cavazos 2008). The opposite rainfall trends in northern and southern Sonora are an example of the great variability typical of semi-arid regions (Comrie \& Broyles 2002). Declining trends in rainfall in the south with an increased trend in the north suggest an expansion of the overall boundaries of the Sonoran Desert in the south and a contraction in the north. This result is different from the results of Weiss \& Overpeck (2005) and the ecological responses of these changes appear to be more complicated than previously assumed. Another example is that $\mathrm{T}_{\min }$ has a negative trend in northern Sonora and $\mathrm{TDT}_{\min \leq 10}$ has a negative trend in southern Sonora.

The extreme values of minimum temperature, TDTmin $\leq 10$, showed negative trends in NBCS, ESBCS, and SSon, which means a decline in cold days. These results correspond well with the finding by Weiss \& Overpeck (2005) of positive trends in monthly minimum temperatures in Sonora. They argued that their results were evidence of the effects of global warming in more frost-free days in the Sonoran Desert. It is possible that their results were influenced by the small amount of data used in their study, which, in certain ways, could mask trends in the extreme values reported in the present study. Still, the correspondence between both studies indicates that the minimum temperature in northwest Mexico is rising, as does a regional climate model that predicts warmer and drier conditions in northwestern Mexico and the southwestern United States (Easterling et al. 2000).

The correlations between historical data trends and the different climatic indices used in the present study 
were heterogeneous, but most of these correlations were statistically significant (Table 3). For example, the correlations between PDO and the measured variables $\mathrm{TDR}_{>0}, \mathrm{~T}_{\min }, \mathrm{TD}_{\min \leq 10}$, and $\mathrm{T}_{\max }$ were statistically significant, which indicates that these variables are governed by climate oscillations of low frequency. However, it is not possible to conclude from the data if the observed tendencies represent an oscillation over very long periods or if their behavior is monotonically decreasing or increasing. The significance of many of the correlations also indicates that the tendencies of these different variables are associated with interdecadal changes in the Pacific and the Atlantic, as well as with variations in patterns of the $700 \mathrm{hPa}$ atmospheric flow, changes in sea surface temperature, intrusions of extratropical fronts, and - at least in the southern Baja California Peninsula - more frequent tropical cyclones.

\section{CONCLUSIONS}

Northwestern Mexico has high meteorological heterogeneity, as observed in spatial and seasonal variability of precipitation and maximum and minimum temperatures. This variability makes it difficult to see a general pattern of warming across the region. In the Baja California Peninsula, we detected a trend towards increased precipitation of similar magnitudes in the southern and northwestern parts of the peninsula. We also detected a decrease (increase) in days with temperatures $\leq 10 \%(\geq 10 \%)$ of the historic minimum (maximum) in the southern part of the peninsula. In contrast to the Baja California Peninsula, some regions of Sonora have trends toward reduced minimum and maximum temperatures, reduced annual rainfall, and fewer days when the minimum temperature was $\leq 10 \%$ of the historical minimum.

Acknowledgements. This study was supported by Consejo Nacional de Ciencia y Tecnología (project nos. M0029-20061-42027, J5075-F, and S0013-2006-1-48492). O.G.G.R. is a recipient of a CONACYT doctoral student fellowship.

\section{LITERATURE CITED}

Barnston G, Livezey RE (1987) Classification, seasonality and low-frequency atmospheric circulation patterns. Mon Weather Rev 115:1083-1126

Brito-Castillo L, Douglas AV, Leyva-Contreras A, Lluch-Belda D (2003) The effect of large-scale circulation on precipitation and streamflow in the Gulf of California continental watershed. Int J Climatol 23:751-768

Brito-Castillo L, Díaz-Castro SC, Ulloa-Herrera RS (2009) Observed tendencies in maximum and minimum temperatures in Zacatecas, Mexico and possible causes. Int J Climatol 29:211-221
BOM (Bureau of Meteorology) (2010) Southern Oscillation Index. Bureau of Meteorology, Melbourne, available at www.bom.gov.au/climate/current/soi2.shtml

Brown ME, Funk CC (2008) Food security under climate change. Science 319:580-581

Cavazos T (2008) Climate change in the North American Monsoon. In: Barnes M, Cavazos T, Díaz R, Doster S and others (eds) Border climate summary, October 2008. Climate Assessment for the Southwest, Tucson, AZ, p 1, 3-4. www.climas.arizona.edu/files/climas/pdfs/periodicals/ BorderClimateSummary_Oct08.pdf

Cavazos T, Rivas D (2004) Variability of extreme precipitation events in Tijuana, Mexico. Clim Res 25:229-243

Cavazos T, Turrent C, Lettenmaier DP (2008) Extreme precipitation trends associated with tropical cyclones in the core of North American monsoon. Geophys Res Lett 35:L21703, doi 10.1029/2008GL035832

Comrie AC, Broyles NB (2002) Variability and spatial modeling of fine-scale precipitation data for the Sonoran Desert of south-west Arizona. J Arid Environ 50:573-592

Comrie AC, Glenn EC (1998) Principal components-based regionalization of precipitation regimes across the southwest Unites States and northern Mexico, with an application to monsoon precipitation variability. Clim Res 10: 201-215

Díaz SC, Salinas-Zavala A, Hernández-Vázquez S (2008) Variability of rainfall from tropical cyclones in northwestern Mexico and its relation to SOI and PDO. Atmosfera 21: 213-223

Douglas MW, Maddox RA, Howard K (1993) The Mexican monsoon. Mon Weather Rev 10:1851-1862

Easterling DR, Meehl GA, Parmesan C, Changnon SA, Karl TR, Mearns LO (2000) Climate extremes: observations, modeling and impacts. Science 289:2068-2074

Enfield DB, Mestas-Nuñez AM, Trimble PJ (2001) The Atlantic multidecadal oscillation and its relation to rainfall and river in the continental U.S. Geophys Res Lett 28: 2077-2080

- Englehart PJ, Douglas AV (2005) Changing behavior in the diurnal range of surface air temperature over Mexico. Geophys Res Lett 32:L01701. doi:10.1029/2004GL021139

Ezcurra E, Rodríguez V (1986) Rainfall patterns in the Gran Desierto, Sonora, Mexico. J Arid Environ 10:13-28

Hastings JR, Turner RM (1965) Seasonal precipitation regimes in Baja California, Mexico. Geogr Ann Ser A 47:204-223

- Heino R, Brazdil R, Forland E, Tuomenvirta H and others (1999) Progress in the study of climate extremes in northern and central Europe. Clim Change 42:151-181

Hoyos CD, Aguadelo PA, Webster PJ, Cury JA (2006) Deconvolution of the factors contributing to the increase in global hurricane intensity. Science 312:94-97

IPCC (Intergovernmental Panel on Climate Change) (2007) Climate change 2007: the physical science basis. Contribution of Working Group I to the Fourth Assessment Report of the Intergovernmental Panel on Climate Change [Solomon S, Qin D, Manning M, Chen Z, Marquis M, Averyt KB, Tignor M, Miller HL (eds)]. Cambridge University Press, Cambridge

Jones PD, Horton EB, Folland CK, Hulme M, Parker DE, Basnett TA (1999) The use of indices to identify changes in climatic extremes. Clim Change 42:131-149

Karl TR, Easterling DR (1999) Climate extremes: selected review and future research directions. Clim Change 42: 309-325

Mantua NJ, Hare SR, Zhang Y, Wallace JM, Francis RC (1997) A Pacific decadal climate oscillation with impacts on salmon production. Bull Am Meteorol Soc 78:1069-1079 
Milly PCD, Betancourt J, Falkenmark M, Hirsch RM and others (2008) Stationarity is dead: Whither water management? Science 319:573-574

NOAA (2002) Monitoring weather and climate. NOAA/National Weather Service, Climate Prediction Center, Camp Springs, MD. Available at www.cpc.noaa.gov/products/precip/ CWlink/pna/nao_index.html

NOAA ESRL (NOAA Earth System Research Laboratory) (2006) NOAA Earth System Research Laboratory, Boulder, CO. www.esrl.noaa.gov/psd/data/composites/datasets.html

North GR, Bell TL, Cahalan RF, Moeng FJ (1982) Sampling errors in the estimation of empirical orthogonal functions. Mon Weather Rev 110:699-706

Overpeck JT, Cole JE (2006) Abrupt change in Earth system. Annu Rev Environ Resour 31:1-31

Pavía EG, Graef F (2002) The recent rainfall climatology of the Mediterranean Californias. J Clim 15:2697-2701

Pavía EG, Graef F, Reyes J (2006) Notes and correspondence PDO-ENSO effects in the climate of Mexico. J Clim 19: 6433-6438

Schmidt R (1989) The arid zones of Mexico: climatic extremes and conceptualization of the Sonoran Desert.

Editorial responsibility: Mikhail Semenov,

Harpenden, UK
J Arid Environ 16:241-256

Seager R, Ting M, Held I, Kushnir Y and others (2007) Model projections of an imminent transition to a more arid climate in Southwestern North America. Science 316:1181-1184

Shreve F (1914) The role of winter temperature in determining the distribution of plants. Am J Bot 1:194-202

Shreve F (1944) Rainfall of northern Mexico. Ecology 25: $105-111$

Thielen DR, Centeno RL (2007) Gradual vs abrupto: necesidad de definir mejor el paradigma del cambio climático y los procesos naturales y sociales. Interciencia 32-3:167-174

Turner RM, Webb RH, Bowers JE, Hastings JR (2003) The changing mile revisited. University of Arizona Press, Tucson

> Vera C, Higgins W, Amador J, Ambrizzi T and others (2006) Toward a unified view of the American monsoon systems. J Clim 19:4977-5000

> Weiss JL, Overpeck JT (2005) Is the Sonoran Desert losing its cool? Global Change Biol 11:2065-2077

> Yan Z, Jones PD, Davies TD, Moberg A and others (2002) Trends of extreme temperatures in Europe and China base on daily observations. Clim Change 53:355-392

Submitted: September 23, 2010; Accepted: April 30, 2010 Proofs received from author(s): June 22, 2010 